\title{
Prolonging myocardial preservation with a modified University of Wisconsin solution containing 2,3-butanedione monoxime and calcium
}

The University of Wisconsin solution is an effective preservative for cold storage of the cardiac allograft. In an earlier study we showed that addition of calcium and 2,3-butanedione monoxime, a reversible inhibitor of myocardial contracture, further improved preservation of the rabbit heart. In this study we investigated the following: (1) the effects of different concentrations of 2,3-butanedione monoxime and calcium on function of the preserved rabbit heart, (2) how heart preservation is affected when 2,3-butanedione monoxime and calcium are added to the St. Thomas' Hospital and Stanford solutions, and (3) how 2,3-butanedione monoxime and calcium, at optimal concentrations in University of Wisconsin solution, affect hearts preserved up to 48 hours. Rabbit hearts were flushed with

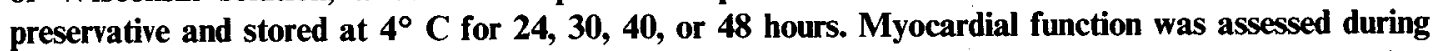
60 minutes of isolated reperfusion, and myocardial adenine nucleotide content was measured after completion of reperfusion. Three concentrations of 2,3-butanedione monoxime $(15,30$, and $60 \mathrm{mmol} /$ L) in the University of Wisconsin solution were studied in hearts preserved for $\mathbf{3 0}$ hours. Storage with 2,3-butanedione monoxime at $30 \mathrm{mmol} / \mathrm{L}$ resulted in significantly better left ventricular developed pressure $(p<0.01)$, left ventricular end-diastolic volume $(p<0.01)$, rate of left ventricular pressure rise $(p<0.01)$, coronary flow $(p<0.05)$, rate-pressure product $(p<0.001)$, and adenine nucleotide regeneration $(p<0.05)$ than with $60 \mathrm{mmol} / \mathrm{L}$, although function was not significantly different when the osmolarity of the solutions was equalized. There was significant reduction in end-diastolic volume $(p<0.05)$ and adenine nucleotide recovery $(p<0.01)$ when 2,3 -butanedione monoxime was lowered to $15 \mathrm{mmol} / \mathrm{L}$. Decreasing the calcium concentration from 1.0 to $0.1 \mathrm{mmol} / \mathrm{L}$ also had a deleterious effect on myocardial function $(p<0.05)$. The addition of $30 \mathrm{mmol} / \mathrm{L} 2,3$-butanedione monoxime and $1.0 \mathrm{mmol} / \mathrm{L}$ calcium to the St. Thomas' or Stanford solutions improved preservation of the heart when compared with the unmodified solutions, but to a lesser degree than with the modified University of Wisconsin solution. After $\mathbf{2 4}$ to $\mathbf{4 8}$ hours of storage in University of Wisconsin solution containing $\mathbf{3 0}$ $\mathrm{mmol} / \mathrm{L}$ 2,3-butanedione monoxime and $1.0 \mathrm{mmol} / \mathrm{L}$ calcium, there was substantial improvement in developed pressure $(p<0.001)$, end-diastolic volume $(p<0.05)$, and rate pressure product $(p<0.001)$, although there was little effect on heart rate and coronary flow, when compared with the unmodified University of Wisconsin solution. We conclude that modification of the University of Wisconsin solution with $30 \mathrm{mmol} / \mathrm{L}$ 2,3-butanedione monoxime and $1.0 \mathrm{mmol} / \mathrm{L}$ calcium significantly improves long-term preservation of the rabbit heart. Further extension in preservation might be accomplished by optimizing the osmolarity of this modified solution. (J THORAC CARDIOVASC SURG 1994;107:764-75)

James C. Stringham, MD, ${ }^{a}$ Karen L. Paulsen, BS, ${ }^{a}$ James H. Southard, PhD, Robert M. Mentzer, Jr., MD, ${ }^{a}$ and Folkert O. Belzer, MD, ${ }^{b}$ Madison, Wis.

From the Division of Cardiothoracic Surgery and Department of Sur-

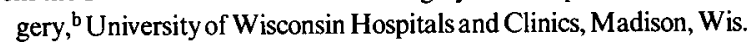

Supported by grants from the University of Wisconsin School of Medicine and the University of Wisconsin Surgical Associates.

Received for publication April 9, 1993.

Accepted for publication Aug. 20, 1993.
Address for reprints: James Stringham, MD, Division of Cardiothoracic Surgery, University of Wisconsin Hospitals and Clinics, 600 Highland Ave., Madison, WI 53792.

Copyright $\odot 1994$ by Mosby-Year Book, Inc.

$0022-5223 / 94 \$ 3.00+0 \quad \mathbf{1 2} / \mathbf{1} / \mathbf{5 0 9 3 2}$ 
Development of the University of Wisconsin solution has had a marked impact on the transplantation of intraabdominal organs. The kidney, liver, and pancreas can be successfully stored for extended periods, ${ }^{1}$ allowing virtual coast-to-coast searches for suitable replacement organs and providing the time necessary to improve immunologic matching and decrease logistic and manpower needs. Most of these transplantations can now be performed on a semielective basis. University of Wisconsin solution has virtually become the standard for intraabdominal organ preservation.

University of Wisconsin solution has also successfully preserved the human cardiac allograft, ${ }^{2}$ but significant extension of the currently accepted limits for ischemic storage has not yet been realized in the clinical setting. Experimental studies have suggested, however, that heart storage with University of Wisconsin solution may safely increase the current limits of 4 to 6 hours up to 8 to 12 hours. ${ }^{3,4}$ Although this method is clearly an improvement over previous methods of myocardial cold storage, there still remains a rather stark contrast between this interval and the experimental storage intervals of 24 to 72 hours obtained for the kidney, liver, and pancreas. ${ }^{5-7}$

A major difference between prolonged ischemic storage of the heart and these other organs is the gradual development of myocardial contracture as a consequence of adenosine triphosphate depletion. ${ }^{8}$ We recently reported that modification of University of Wisconsin solution with calcium chloride and a reversible contractile inhibitor, 2,3-butanedione monoxime (BDM), resulted in elimination of ischemic contracture and resumption of near-normal myocardial function after 24-hour cold storage of the rabbit heart. ${ }^{9}$ It is still unclear, however, what the optimal concentration of BDM and calcium should be and whether equivalent protection is afforded by adding BDM and calcium to other commonly used preservation solutions. This study addresses these issues and quantitates the amount of myocardial protection afforded by BDM and calcium when preservation is extended beyond 24 hours.

\section{Materials and methods}

Experimental animals were treated humanely in compliance with the "Principles of Laboratory Animal Care" formulated by the National Society for Medical Research and the "Guide for the Care and Use of Laboratory Animals" prepared by the Institute of Laboratory Animal Resources and published by the National Institutes of Health (NIH publication No. 86-23, revised 1985).

Our experimental protocol has been previously described in detail $^{9}$ and was used in this study with only minor modification. In brief, hearts were harvested from adult New Zealand White rabbits ( 1.6 to $2.7 \mathrm{~kg}$ ) via a median sternotomy after receiving intravenous ketamine anesthesia $(25 \mathrm{mg} / \mathrm{kg}$ ) and intravenous heparin (1000 U), and undergoing tracheostomy, chemical paralysis, and mechanical ventilation of the lungs. Hearts were excised after achieving mechanical arrest with an intravenous injection of $\mathrm{KCl}(4 \mathrm{mEq})$ and were immediately placed in $4^{\circ} \mathrm{C}$ storage solution. The coronary circulation was then flushed with $50 \mathrm{ml}$ of storage solution at $4^{\circ} \mathrm{C}$ at a perfusion pressure of 50 $\mathrm{cm} \mathrm{H}_{2} \mathrm{O}$.

After flushing, hearts were weighed, immersed in storage solution, surrounded with crushed ice, and stored in a refrigerated room at $4^{\circ} \mathrm{C}$. The hearts of each experimental group were stored for 30 hours because previous storage for 24 hours resulted in near-control function, ${ }^{9}$ and differences between experimental groups were not readily apparent with the minor damage associated with 24 hours of cold ischemia. Control hearts were flushed but underwent no storage. All hearts were then mounted on a modified Langendorff column for reperfusion and functional assessment. Reperfusion was performed for 60 minutes at $37^{\circ} \mathrm{C}$ with a diastolic perfusion pressure of approximately $70 \mathrm{~mm} \mathrm{Hg}$. The reperfusate consisted of a modified Krebs-Henseleit buffer containing $\mathrm{NaHCO}_{3}, 25 \mathrm{mmol} / \mathrm{L}$; $\mathrm{KH}_{2} \mathrm{PO}_{4}, 1.2 \mathrm{mmol} / \mathrm{L} ; \mathrm{NaCl}, 118 \mathrm{mmol} / \mathrm{L} ; \mathrm{KCl}, 4.7 \mathrm{mmol} / \mathrm{L}$; $\mathrm{MgSO}_{4}, 1.2 \mathrm{mmol} / \mathrm{L} ; \mathrm{CaCl}_{2}, 2 \mathrm{mmol} / \mathrm{L}$; dextrose, $10 \mathrm{mmol} /$ $\mathrm{L}$, and was bubbled to equilibration with $95 \%$ oxygen and $5 \%$ carbon dioxide (oxygen tension was 450 to 600 ).

Ventricular function was assessed with a fluid-filled left ventricular latex balloon, which approximated the normal rabbit ventricular volume when inflated to $1.0 \mathrm{ml}$. Hemodynamic data were continuously monitored on a multichannel recorder, and the maximum values attained during reperfusion were compared. Measurement of heart rate and systolic pressure was recorded at 15-minute intervals by inflating the balloon to an end-diastolic pressure of $20 \mathrm{~mm} \mathrm{Hg}$. The balloon was deflated to $0.1 \mathrm{ml}$ between data collection points to avoid subendocardial ischemia from continuous pressure of the inflated balloon on the irregular inner ventricular contour. Left ventricular end-diastolic volume (LVEDV), an indicator of postischemic diastolic relaxation, was measured from the balloon volume that was necessary to create an end-diastolic pressure of $20 \mathrm{~mm} \mathrm{Hg}$. Coronary flow was determined at the same intervals by a 30 -second collection of effluent from the heart, and the maximum rate of left ventricular pressure rise $(\mathrm{dP} / \mathrm{dt})$ was recorded by a direct differentiation of the pressure waveform.

Comparisons of systolic function were performed at constant end-diastolic pressure instead of constant LVEDV because of the variability in the size of hearts studied and the severe postischemic contracture that developed in some hearts. Pilot studies showed that, had measurements at constant LVEDV been attempted, supranormal pressures of 50 to $60 \mathrm{~mm} \mathrm{Hg}$ would have been reached in hearts that had undergone contracture. These measurements would have resulted in mechanical stretching of the myocardium, thus making comparisons of either systolic or diastolic function under these circumstances unreliable and irreproducible on later measurements. Evaluation of systolic function at constant end-diastolic pressure allowed comparison under more physiologic conditions without mechanical damage to the myocardium but may have introduced a small degree of bias into interpretation of the data because of the variability in diastolic volumes.

Left ventricular developed pressure (LVDP) was calculated by subtracting end-diastolic pressure from systolic pressure. Coronary flow and LVEDV were corrected for myocardial mass 
Table I. Composition of preservation solutions

\begin{tabular}{lccccc}
\hline \multicolumn{1}{c}{$\begin{array}{c}\text { University of } \\
\text { Wisconsin solution }\end{array}$} & Concentration & $\begin{array}{c}\text { St. Thomas' } \\
\text { Hospital solution }\end{array}$ & Concentration & $\begin{array}{c}\text { Stanford } \\
\text { solution }\end{array}$ & Concentration \\
\hline K-lactobionate & $100 \mathrm{mmol} / \mathrm{L}$ & $\mathrm{NaCl}$ & $110 \mathrm{mmol} / \mathrm{L}$ & Dextrose & $50 \mathrm{gm} / \mathrm{L}$ \\
Raffinose & $30 \mathrm{mmol} / \mathrm{L}$ & $\mathrm{KCl}$ & $16 \mathrm{mmol} / \mathrm{L}$ & $\mathrm{KCl}$ & $15 \mathrm{mmol} / \mathrm{L}$ \\
$\mathrm{Na}^{*}$ & $25 \mathrm{mmol} / \mathrm{L}$ & $\mathrm{NaHCO}_{3}$ & $10 \mathrm{mmol} / \mathrm{L}$ & $\mathrm{NaHCO}$ & $25 \mathrm{mmol} / \mathrm{L}$ \\
$\mathrm{KH}_{2} \mathrm{PO}_{4}$ & $25 \mathrm{mmol} / \mathrm{L}$ & $\mathrm{MgCl}_{2}$ & $16 \mathrm{mmol} / \mathrm{L}$ & $\mathrm{Mannitol}$ & $12.5 \mathrm{gm} / \mathrm{L}$ \\
Adenosine $_{\mathrm{MgSO}}$ & $5 \mathrm{mmol} / \mathrm{L}$ & $\mathrm{CaCl}_{2}$ & $1.2 \mathrm{mmol} / \mathrm{L}$ & & \\
Glutathione & $5 \mathrm{mmol} / \mathrm{L}$ & & & \\
Allopurinol & $3 \mathrm{mmol} / \mathrm{L}$ & & & \\
Hydroxyethyl starch & $1 \mathrm{mmol} / \mathrm{L}$ & & & \\
Insulin & $50 \mathrm{gm} / \mathrm{L}$ & & & \\
Dexamethasone & $100 \mathrm{U} / \mathrm{L}$ & & & \\
TMP-SMZ & $16 \mathrm{mg} / \mathrm{L}$ & & & \\
pH & $160 \mathrm{mg}-32 \mathrm{mg} / \mathrm{L}$ & & $3.8 \mathrm{mOsm} / \mathrm{L}$ & & \\
Osmolarity & 7.4 & & & $440 \mathrm{mOsm} / \mathrm{L}$ \\
\hline
\end{tabular}

TMP-SMZ, Trimethoprim sulfamethoxazole.

${ }^{*} \mathrm{pH}$ of University of Wisconsin solution adjusted with $\mathrm{NaOH}(25 \mathrm{mmol} / \mathrm{L})$ and $\mathrm{KOH}$ as needed.

by dividing each value by the prepreservation heart weight. The rate-pressure product was calculated by multiplying the heart rate and LVDP. After 60 minutes of reperfusion, hearts were rapidly removed from the column and frozen in liquid nitrogen. The frozen myocardium was then crushed and stored at $-70^{\circ}$ C. Adenine nucleotide content was later determined in duplicate from these samples by high-performance liquid chromatography. ${ }^{9}$

Storage solutions (Table I) were prepared fresh in our laboratory and used within 24 hours. BDM was added to University of Wisconsin solution in concentrations of $15 \mathrm{mmol} / \mathrm{L}$ (Group 1), $30 \mathrm{mmol} / \mathrm{L}$ (Group 2), and $60 \mathrm{mmol} / \mathrm{L}$ (Group 3). Addition of $60 \mathrm{mmol} / \mathrm{L} \mathrm{BDM}$ resulted in a calculated osmolarity of approximately $380 \mathrm{mOsm} / \mathrm{L}$, which was based on the known osmolarity of standard University of Wisconsin solution of 320 $\mathrm{mOsm} / \mathrm{L}$. $\mathrm{K}^{+}$and lactobionate concentrations were both reduced by $15 \mathrm{mmol} / \mathrm{L}$ (Group 4) to compensate for this discrepancy to create an osmolarity equivalent to that of Group 2-approximately $350 \mathrm{mOsm} / \mathrm{L}$. Calcium concentration was compared at $1.0 \mathrm{mmol} / \mathrm{L}$ (Group 2) and $0.1 \mathrm{mmol} / \mathrm{L}$ (Group 5 ), with $\mathrm{BDM}$ concentration at $30 \mathrm{mmol} / \mathrm{L}$ in both groups. Control hearts were flushed with University of Wisconsin solution containing BDM $30 \mathrm{mmol} / \mathrm{L}$ and $\mathrm{CaCl}_{2} 1.0 \mathrm{mmol} / \mathrm{L}$ and immediately reperfused. Groups 1 to 5 , with their respective solution modifications, are listed in Table II. University of Wisconsin solution, with and without $\mathrm{BDM} 30 \mathrm{mmol} / \mathrm{L}$ and $\mathrm{CaCl}_{2}$ $1.0 \mathrm{mmol} / \mathrm{L}$, was compared with both the Stanford solution and the St. Thomas' Hospital cardioplegic solution, either alone or modified with BDM $30 \mathrm{mmol} / \mathrm{L}$ and $\mathrm{CaCl}_{2} 1.0 \mathrm{mmol} / \mathrm{L}$. The composition of Stanford solution ${ }^{10}$ and St. Thomas' Hospital solution ${ }^{11}$ was described previously (Table I). Calcium was not added to the modified St. Thomas' Hospital solution because it normally contains $\mathrm{CaCl}_{2} 1.2 \mathrm{mmol} / \mathrm{L}$. Finally, standard University of Wisconsin solution was compared with modified University of Wisconsin solution containing BDM $30 \mathrm{mmol} / \mathrm{L}$ and $\mathrm{CaCl}_{2} 1.0 \mathrm{mmol} / \mathrm{L}$ after $24,30,40$, and 48 hours of preservation to assess the length of protection afforded by these modifications.

Results for each group are expressed as the mean \pm standard error. Multiple group comparisons were performed by analysis of variance with adjustment by the Bonferroni method. The means of two corresponding groups were compared by a two-tailed Student's $t$ test. Statistical analysis was performed with Instat statistical software (Graphpad, San Diego, Calif.), and differences were considered significant at $p<0.05$.

\section{Results}

After 30 hours of storage, all hearts defibrillated spontaneously and resumed a sinus rhythm. All groups exhibited some degree of myocardial dysfunction (Table II) as a result of the prolonged ischemic storage interval.

BDM concentration. The addition of $30 \mathrm{mmol} / \mathrm{L}$ BDM to University of Wisconsin solution resulted in superior postischemic function compared with other BDM concentrations tested (Fig. 1). LVDP returned to $75 \%$ of control compared with $66 \%$ of control with 15 $\mathrm{mmol} / \mathrm{L}$, and $41 \%$ with $60 \mathrm{mmol} / \mathrm{L}(p<0.01)$. LVEDV returned to $74 \%$ of control with $\mathrm{BDM} 30 \mathrm{mmol} / \mathrm{L}, 38 \%$ with $15 \mathrm{mmol} / \mathrm{L}(p<0.05)$, and $35 \%$ by adding $\mathrm{BDM} 60$ $\mathrm{mmol} / \mathrm{L}$ in the preservative $(p<0.01)$. Most hearts experienced some degree of sinus tachycardia that did not correlate with the concentration of BDM in solution. Heart rates ranged from $117 \%$ of control value with BDM $30 \mathrm{mmol} / \mathrm{L}$, to $109 \%$ with $15 \mathrm{mmol} / \mathrm{L}$, and $100 \%$ of baseline with $60 \mathrm{mmol} / \mathrm{L}$. Thus, the use of BDM was associated with a pronounced effect on the automaticity and integrity of the conduction system, as bradycardia is often the result of ischemic myocardial damage and was not seen in any group.

Coronary flow was reduced in all hearts studied, returning to $69 \%$ of control in hearts stored with BDM 30 $\mathrm{mmol} / \mathrm{L}, 60 \%$ with $15 \mathrm{mmol} / \mathrm{L}$, and $38 \%$ for $60 \mathrm{mmol} / \mathrm{L}$ ( $p<0.05$ versus $30 \mathrm{mmol} / \mathrm{L}$ ). $\mathrm{dP} / \mathrm{dt}$ was also best with $30 \mathrm{mmol} / \mathrm{L}$, resuming $78 \%$ of control value versus $64 \%$ 


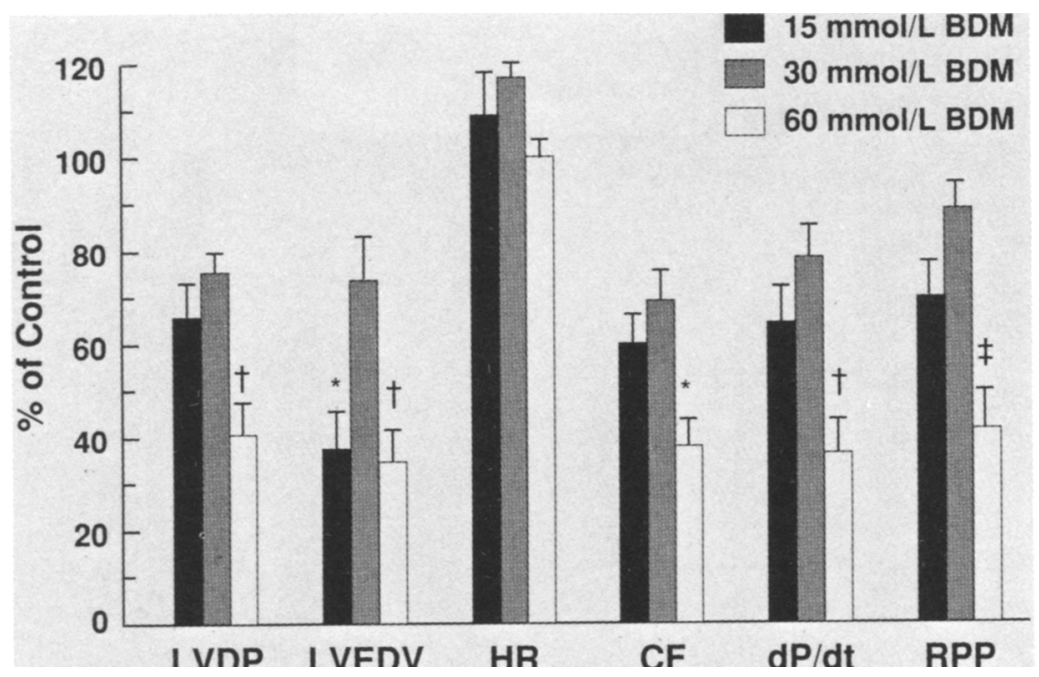

Fig. 1. Function of hearts cold stored 30 hours in University of Wisconsin solution modified with varying concentrations of BDM. Values shown represent the mean \pm standard error for each group, as a percentage of control. Absolute values are shown in Table II. Statistical comparisons performed by analysis of variance, comparing each group that containing BDM $30 \mathrm{mmol} / \mathrm{L} . H R$, Heart rate; $C F$, coronary flow; $d P / d t$, rate of left ventricular pressure rise; $R P P$, rate pressure product. ${ }^{*} p<0.05, \dagger p<0.01, \ddagger p<0.001$.

Table II. Function of hearts cold stored 30 hours in University of Wisconsin solution modified with BDM and calcium

\begin{tabular}{lcccccc}
\hline & $\begin{array}{c}\text { Control } \\
(n=7)\end{array}$ & $\begin{array}{c}\text { Group } ~ \\
(n=6)\end{array}$ & $\begin{array}{c}\text { Group 2 } \\
(n=7)\end{array}$ & $\begin{array}{c}\text { Group 3 } \\
(n=7)\end{array}$ & $\begin{array}{c}\text { Group 4 } \\
(n=6)\end{array}$ & $\begin{array}{c}\text { Group 5 } \\
(n=6)\end{array}$ \\
\hline BDM $(\mathrm{mmol} / \mathrm{L})$ & 30 & 15 & 30 & 60 & $60^{*}$ & 30 \\
$\mathrm{Ca}(\mathrm{mmol} / \mathrm{L})$ & 1.0 & 1.0 & 1.0 & 1.0 & 1.0 & 0.1 \\
LVDP $(\mathrm{mm} \mathrm{Hg})$ & $121.0 \pm 3.8$ & $79.5 \pm 8.8$ & $91.1 \pm 5.4$ & $49.0 \pm 8.7$ & $80.0 \pm 7.9$ & $60.0 \pm 9.3$ \\
LVEDV $(\mu \mathrm{l} / \mathrm{gm})$ & $227.4 \pm 6.7$ & $84.8 \pm 18.4$ & $167.1 \pm 20.9$ & $78.9 \pm 15.6$ & $140.0 \pm 15.7$ & $93.2 \pm 37.1$ \\
HR $\left(\mathrm{min}^{-1}\right)$ & $191 \pm 7$ & $208 \pm 18$ & $224 \pm 5$ & $191 \pm 8$ & $231 \pm 18$ & $192 \pm 24$ \\
$\mathrm{CF}(\mathrm{ml} / \mathrm{gm} / \mathrm{min})$ & $12.6 \pm 0.9$ & $7.6 \pm 0.8$ & $8.7 \pm 0.8$ & $4.8 \pm 0.7$ & $7.7 \pm 0.6$ & $7.8 \pm 0.3$ \\
$\mathrm{dP} / \mathrm{dt}(\mathrm{mm} \mathrm{Hg} / \mathrm{sec})$ & $2097 \pm 75$ & $1348 \pm 160$ & $1646 \pm 142$ & $761 \pm 167$ & $1190 \pm 129$ & $933 \pm 143$ \\
RPP $(\mathrm{mm} \mathrm{Hg} / \mathrm{min})$ & $23100 \pm 1376$ & $16138 \pm 1684$ & $20474 \pm 1376$ & $9596 \pm 1984$ & $18114 \pm 1806$ & $10863 \pm 1704$ \\
\hline
\end{tabular}

Control hearts were immediately reperfused without storage. Values represent the mean \pm standard error for each group. $H R$, Heart rate; $C F$, coronary flow; $\boldsymbol{R P P}$, rate pressure product.

*Reduced osmolarity by $30 \mathrm{mmol} / \mathrm{L}$.

with $15 \mathrm{mmol} / \mathrm{L}$ and $36 \%$ with $60 \mathrm{mmol} / \mathrm{L}(p<0.01)$. Rate-pressure product followed the same trend, with $89 \%$ of control with $30 \mathrm{mmol} / \mathrm{L}$, compared with $70 \%$ with 15 $\mathrm{mmol} / \mathrm{L}$, and only $42 \%$ with $60 \mathrm{mmol} / \mathrm{L}(p<0.001)$.

With respect to regeneration of adenine nucleotide stores on reperfusion, total adenine nucleotides, adenosine triphosphate, adenosine diphosphate, and adenosine monophosphate content all returned to control values when hearts were stored 30 hours in the presence of BDM $30 \mathrm{mmol} / \mathrm{L}$ (Fig. 2). In contrast, storage with BDM 15 $\mathrm{mmol} / \mathrm{L}$ resulted in return of only $43 \%$ of adenosine triphosphate content $(p<0.01)$ and $65 \%$ of total adenine nucleotides content $(p<0.01)$. Storage with BDM 60 $\mathrm{mmol} / \mathrm{L}$ produced recovery of $68 \%$ of adenosine triphosphate and $74 \%$ of total adenine nucleotides content $(p<0.05)$.

Osmolarity. When the osmolarity of the solution containing BDM $60 \mathrm{mmol} / \mathrm{L}$ was reduced from 380 to 350 $\mathrm{mOsm} / \mathrm{L}$, to equal that containing BDM $30 \mathrm{mmol} / \mathrm{L}$, LVDP returned to $66 \%$, LVEDV to $62 \%$, heart rate to $121 \%$, coronary flow to $61 \%, \mathrm{dP} / \mathrm{dt}$ to $57 \%$, and ratepressure product to $78 \%$ of control values (Fig. 3). This was a marked improvement over hearts stored with BDM $60 \mathrm{mmol} / \mathrm{L}$, but at a higher osmolarity, and reached statistical significance in LVDP, coronary flow, and ratepressure product $(p<0.05)$. In addition, these values 


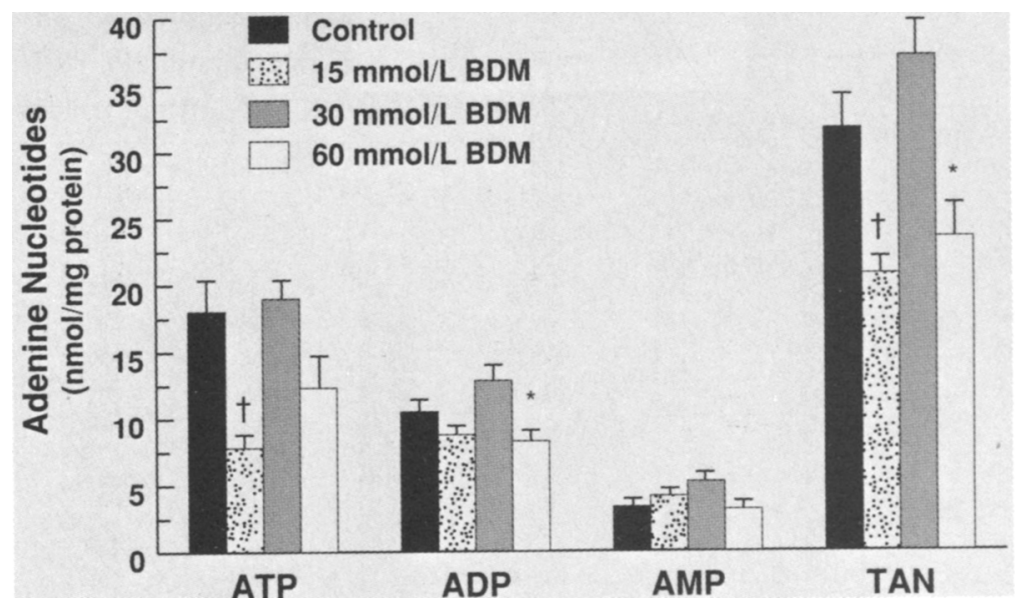

Fig. 2. Adenine nucleotide regeneration after 30 hours of cold storage in University of Wisconsin solution with varying concentrations of BDM and 60-minute reperfusion. Values shown represent the mean \pm standard error for each group. Statistical analysis performed by analysis of variance, comparing each group to that containing BDM $30 \mathrm{mmol} / \mathrm{L}$. Control values are shown for reference only; $n=7$ for controls, 6 for $15 \mathrm{mmol} / \mathrm{L}, 10$ for $30 \mathrm{mmol} / \mathrm{L}$, and 7 for $60 \mathrm{mmol} / \mathrm{L}$ BDM. $A T P$, Adenosine triphosphate; $A D P$, adenosine diphosphate; $A M P$, adenosine monophosphate; $T A N$, total adenine nucleotides. ${ }^{*} p<0.05, \dagger p<0.01$.

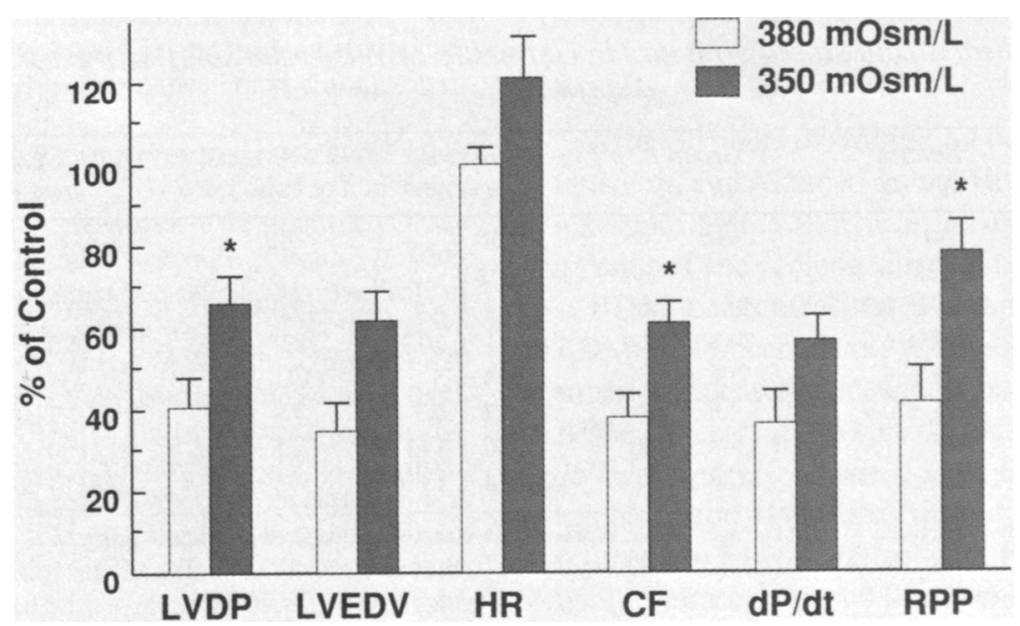

Fig. 3. Function of hearts after 30 hours of cold storage in University of Wisconsin solution modified with BDM $60 \mathrm{mmol} / \mathrm{L}$ and $\mathrm{CaCl}_{2} 1.0 \mathrm{mmol} / \mathrm{L}$ at varying osmolarity. Values shown represent the mean \pm standard error for each group, as a percentage of control. Absolute values shown in Table II; ${ }^{*} p<0.05$. See Fig. 1 for abbreviations.

were only slightly less, but not significantly different, than those obtained by storage with BDM $30 \mathrm{mmol} / \mathrm{L}$. The nucleotide regeneration capacity of this group was also improved, regaining $112 \%$ of control adenosine triphosphate, and $96 \%$ of control total adenine nucleotides (Fig. 4). Adenosine diphosphate and adenosine monophosphate, however, remained at similar concentrations.

Calcium concentration. Micromolar amounts of calcium were insufficient to protect the myocardium during prolonged storage. Hearts stored with $\mathrm{CaCl}_{2} 0.1 \mathrm{mmol} / \mathrm{L}$ in solution recovered only $50 \%$ of control LVDP, $41 \%$ of LVEDV, $62 \%$ of coronary flow, $45 \%$ of $\mathrm{dP} / \mathrm{dt}$, and $47 \%$ of rate-pressure product but maintained $100 \%$ of baseline heart rate (Fig. 5). Storage with $\mathrm{CaCl}_{2} 1.0 \mathrm{mmol} / \mathrm{L}$ resulted in superior function, with $75 \%$ of control LVDP $(p<0.01), 74 \%$ of LVEDV $(p<0.05), 117 \%$ of heart rate ( $p=$ not significant), $69 \%$ of coronary flow ( $p=$ not significant), $78 \%$ of $\mathrm{dP} / \mathrm{dt}(p<0.01)$, and $89 \%$ of RPP $(p<0.001)$.

Regeneration of adenine nucleotides was also reduced 


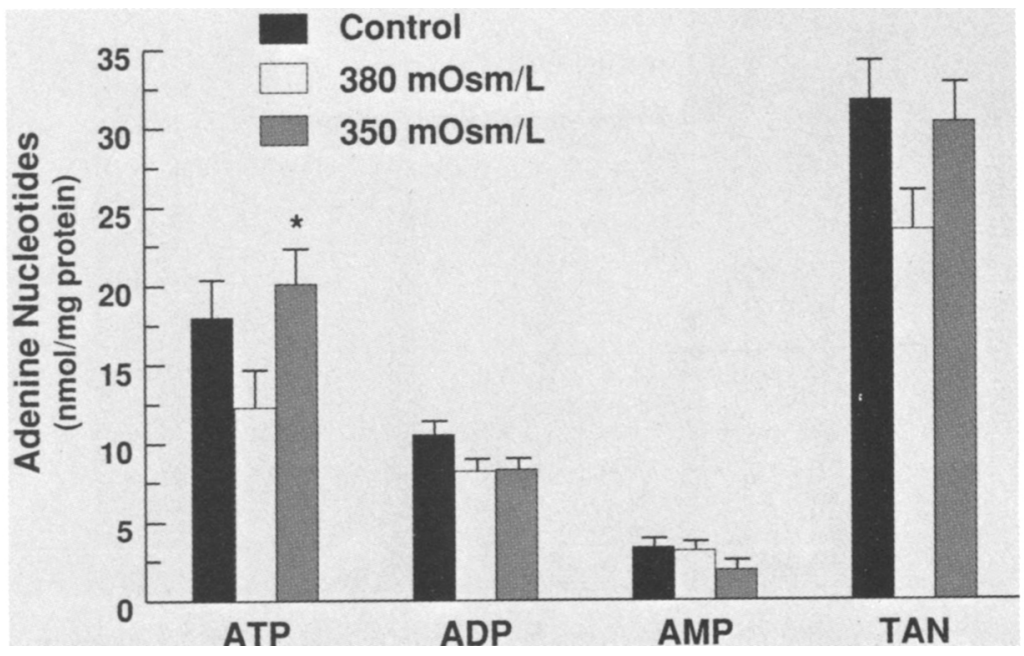

Fig. 4. Myocardial adenine nucleotide content after 30 hours of cold storage in University of Wisconsin solution containing BDM $60 \mathrm{mmol} / \mathrm{L}$ and $\mathrm{CaCl}_{2} 1.0 \mathrm{mmol} / \mathrm{L}$ at varying osmolarity and 60 -minute reperfusion. Values shown represent the mean \pm standard error for each group. Experimental groups were compared by analysis of variance. Control values shown for reference only; $n=7$ for controls, 7 for $380 \mathrm{mOsm} / \mathrm{L}$, and 6 for $350 \mathrm{mOsm} / \mathrm{L},{ }^{*} p<0.05$. See Fig. 2 for abbreviations.

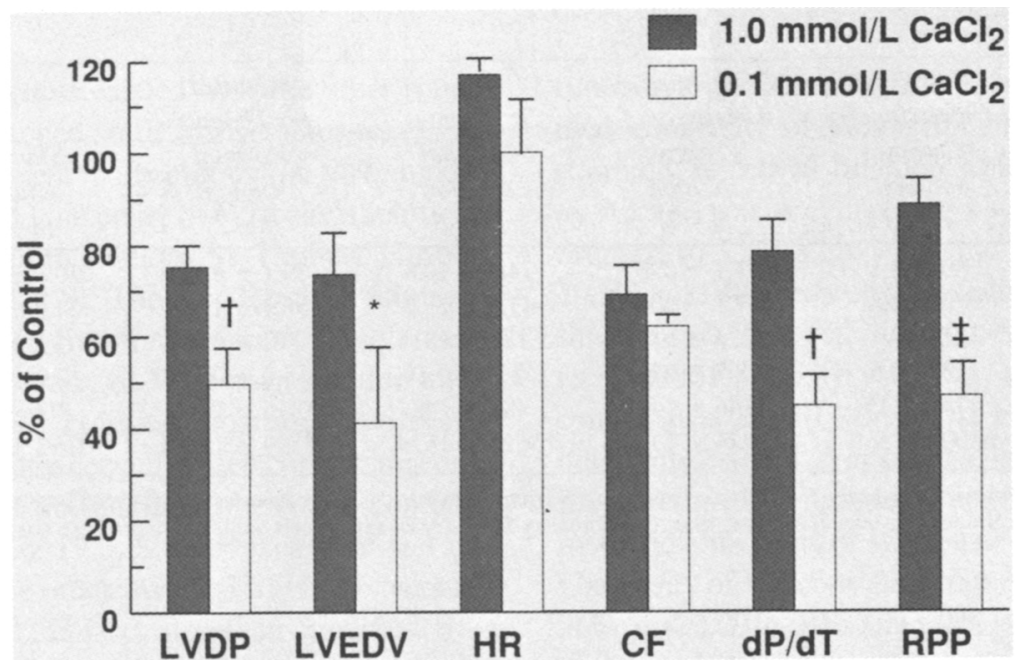

Fig. 5. Function of hearts after 30 hours of cold storage in University of Wisconsin solution modified with BDM $30 \mathrm{mmol} / \mathrm{L}$ and $\mathrm{CaCl}_{2}$, either $1.0 \mathrm{mmol} / \mathrm{L}$ or $0.1 \mathrm{mmol} / \mathrm{L}$. Values shown represent the mean \pm standard error for each group, calculated as a percentage of control. Absolute values are shown in Table II; ${ }^{*} p<0.05, \dagger p<0.01$, $\ddagger p<0.001$. See Fig. 1 for abbreviations.

with $\mathrm{CaCl}_{2} 0.1 \mathrm{mmol} / \mathrm{L}$ (Fig. 6), reaching $47 \%$ of control adenosine triphosphate, and $65 \%$ of total adenine nucleotides. In contrast, hearts exposed to $\mathrm{CaCl}_{2} 1.0$ $\mathrm{mmol} / \mathrm{L}$ during storage regained $106 \%$ of baseline adenosine triphosphate $(p<0.05)$ and $117 \%$ of total adenine nucleotide content $(p<0.01)$.

Preservation solutions. Preservation solutions modified with $\mathrm{BDM} 30 \mathrm{mmol} / \mathrm{L}$ and $\mathrm{CaCl}_{2} 1.0 \mathrm{mmol} / \mathrm{L}$ were found to be consistently superior in preservation capability when compared with their respective unmodified counterparts (Table III). After 30 hours of storage, hearts preserved in University of $\mathrm{W}$ isconsin solution containing BDM and calcium recovered superior LVDP $(p<0.0001)$, LVEDV $(p<0.0001)$, heart rate $(p<$ $0.001), \mathrm{dP} / \mathrm{dt}(p<0.0001)$, and rate-pressure product $(p<0.0001)$ than did those with standard University of 


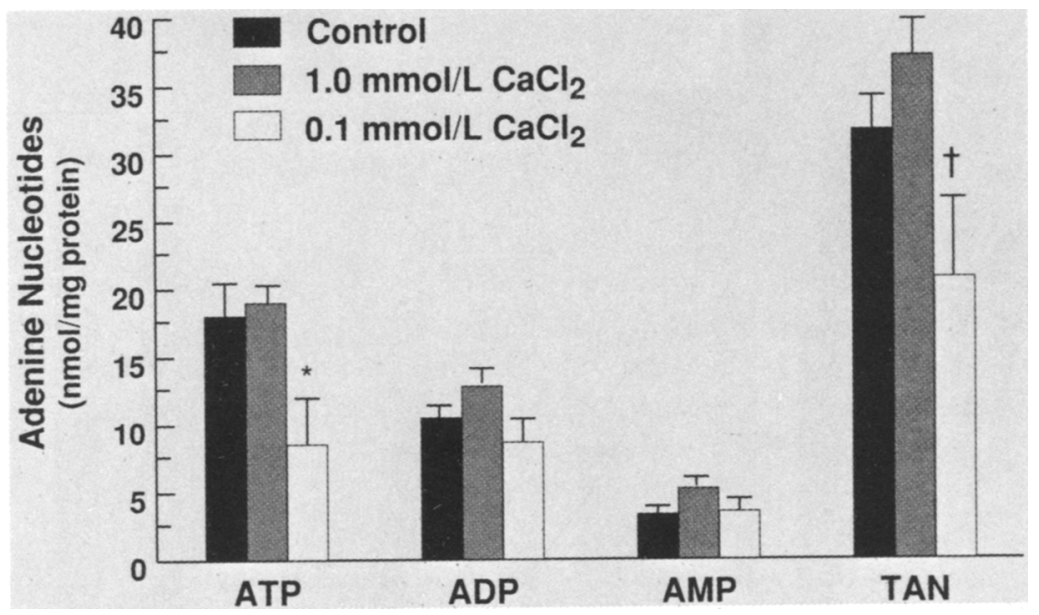

Fig. 6. Myocardial adenine nucleotide regeneration after 30 hours of cold storage in University of Wisconsin solution containing BDM $30 \mathrm{mmol} / \mathrm{L}$ and $\mathrm{CaCl}_{2}$, either $1.0 \mathrm{mmol} / \mathrm{L}$ or $0.1 \mathrm{mmol} / \mathrm{L}$. Values shown represent the mean \pm standard error for each group. Experimental groups were compared by analysis of variance. Control values shown for reference only; $n=7$ for controls, 10 for $\mathrm{CaCl}_{2} 1.0 \mathrm{mmol} / \mathrm{L}$, and 6 for $\mathrm{CaCl}_{2}, 0.1 \mathrm{mmol} / \mathrm{L} ;{ }^{*} p<0.05$, $\dagger p<0.01$. See Fig. 2 for abbreviations.

Table III. Function of hearts cold stored 30 hours in commonly used preservation solutions with and without $B D M$ and calcium

\begin{tabular}{|c|c|c|c|c|c|c|}
\hline & $\begin{array}{c}\text { University of } \\
\text { Wisconsin } \\
\text { solution } \\
(n=8)\end{array}$ & $\begin{array}{l}\text { Modified } \\
\text { University of } \\
\text { Wisconsin } \\
\text { solution } \\
(n=7)\end{array}$ & $\begin{array}{c}\text { St. Thomas' } \\
\text { Hospital } \\
\text { solution } \\
(n=6) \\
\end{array}$ & $\begin{array}{l}\text { Modified } \\
\text { St. Thomas' } \\
\text { Hospital } \\
\text { solution } \\
(n=7)\end{array}$ & $\begin{array}{c}\text { Stanford } \\
\text { solution } \\
(n=6)\end{array}$ & $\begin{array}{c}\text { Modified } \\
\text { Stanford } \\
\text { solution } \\
(n=6)\end{array}$ \\
\hline LVDP $(\mathrm{mm} \mathrm{Hg})$ & $37.0 \pm 8.1$ & $91.1 \pm 5.4^{*}$ & $34.2 \pm 10.8$ & $79.1 \pm 8.2 \dagger$ & $20.8 \pm 4.8$ & $49.3 \pm 12.6$ \\
\hline $\operatorname{LVEDV}(\mu \mathrm{l} / \mathrm{gm})$ & $31.9 \pm 4.8$ & $167.1 \pm 20.9^{*}$ & $47.2 \pm 15.3$ & $150.1 \pm 11.8 \ddagger$ & $28.0 \pm 4.5$ & $74.8 \pm 25.4$ \\
\hline $\mathrm{HR}\left(\min ^{-1}\right)$ & $181 \pm 7$ & $224 \pm 5 \ddagger$ & $180 \pm 13$ & $197 \pm 6$ & $172 \pm 16$ & $171 \pm 16$ \\
\hline $\mathrm{CF}(\mathrm{ml} / \mathrm{gm} / \mathrm{min})$ & $6.8 \pm 0.6$ & $8.7 \pm 0.8$ & $6.3 \pm 0.4 \dagger$ & $5.0 \pm 0.1$ & $7.2 \pm 0.8$ & $7.1 \pm 0.6$ \\
\hline $\mathrm{dP} / \mathrm{dt}(\mathrm{mm} \mathrm{Hg} / \mathrm{sec})$ & $474 \pm 115$ & $1646 \pm 142^{*}$ & $489 \pm 148$ & $1316 \pm 141 \dagger$ & $293 \pm 76$ & $773 \pm 224$ \\
\hline $\mathrm{RPP}(\mathrm{mm} \mathrm{Hg} / \mathrm{min})$ & $6500 \pm 1569$ & $20474 \pm 1376^{*}$ & $5625 \pm 1574$ & $15799 \pm 1839 \dagger$ & $3692 \pm 1099$ & $8883 \pm 2403$ \\
\hline
\end{tabular}

See Methods section. Values represent the mean \pm standard error for each group. Statistical comparisons were performed between each solution and its respective modified counterpart with Student's $t$ test. $H R$, heart rate; $C F$, coronary flow; $d P / d t$, rate of left ventricular pressure rise; $R P P$, rate pressure product. ${ }^{*} p<0.0001$.

$\dagger_{p}<0.01$.

$\ddagger p<0.001$.

Wisconsin solution. Coronary flow in this group was slightly but not significantly higher than that with the unmodified solution.

In hearts preserved with St. Thomas' Hospital solution, addition of BDM resulted in better LVDP $(p<0.01)$, LVEDV $(p<0.001), \mathrm{dP} / \mathrm{dt}(p<0.01)$, and rate-pressure product $(p<0.01)$. Heart rate was unchanged, and coronary flow remained slightly more depressed $(p<0.01)$ than with unmodified St. Thomas' Hospital solution. When Stanford solution was the preservative, LVDP, LVEDV, dP/dt, and rate-pressure product were all improved with addition of BDM and calcium, but these differences did not reach statistical significance. Heart rate and coronary flow were unchanged.

Myocardial adenine nucleotide content was improved only after storage in modified University of Wisconsin solution (Fig. 7). Adenosine triphosphate recovery improved from 8.8 to $19.0 \mathrm{nmol} / \mathrm{mg}$ protein $(p<0.001)$, adenosine diphosphate from 5.5 to $12.8 \mathrm{nmol} / \mathrm{mg}$ protein $(p<0.001)$, adenosine monophosphate from 1.1 to 5.2 $\mathrm{nmol} / \mathrm{mg}$ protein $(p<0.001)$, and total adenine nucleotides from 15.3 to $37.1 \mathrm{nmol} / \mathrm{mg}$ protein $(p<0.0001)$ with storage in University of Wisconsin solution and modified University of Wisconsin solution, respectively. 


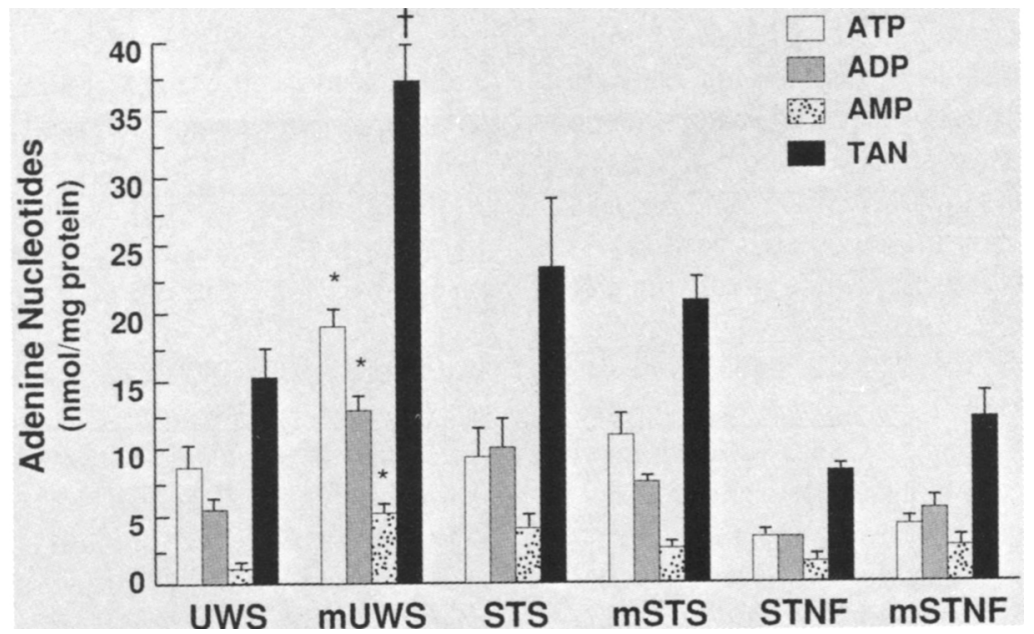

Fig. 7. Adenine nucleotides regenerated after 30 hours of cold storage in solutions with and without BDM 30 $\mathrm{mmol} / \mathrm{L}$ and $\mathrm{CaCl}_{2} 1.0 \mathrm{mmol} / \mathrm{L}$ and subsequent 60 minutes of reperfusion. Values shown represent the mean \pm standard error for each group. Each solution was compared with its respective modified counterpart by Student's $t$ test; $n=6$ for University of Wisconsin solution (UWS), 10 for modified University of Wisconsin solution (mUWS), 6 for St. Thomas' Hospital solution (STS), 7 for modified St. Thomas' Hospital solution (mSTS), 6 for Stanford solution $(S T N F)$, and 6 for modified Stanford solution $(m S T N F) .{ }^{*} p<0.001, \dagger p<0.0001$. See Fig. 2 for other abbreviations.

Although minor differences existed with the other solutions, none of these reached statistical significance.

When comparisons were made among the three modified solutions, modified University of Wisconsin solution was consistently superior to modified St. Thomas' Hospital solution, and modified St. Thomas' Hospital solution was superior to modified Stanford solution. Differences between modified University of Wisconsin solution and modified St. Thomas' Hospital solution, however, reached statistical significance only when comparing coronary flow $(p<0.01)$ and adenine nucleotide content (adenosine triphosphate: $19.0 \pm 1.3$ versus $10.9 \pm 1.6$; $p<0.01$; total adenine nucleotides $37.1 \pm 2.6$ versus $20.8 \pm 1.7 ; p<0.001)$. Hearts stored in modified St. Thomas' Hospital solution performed better than those stored in modified Stanford solution in all parameters except coronary flow, but reached statistical significance only in adenosine triphosphate concentration $(20.8 \pm 1.7$ versus $4.2 \pm 0.6 ; p<0.05)$. Storage in modified University of Wisconsin solution resulted in better performance than storage in modified Stanford solution in LVDP $(p<0.05)$, LVEDV $(p<0.05)$, heart rate $(p<0.01)$, $\mathrm{dP} / \mathrm{dt}(p<0.05)$, rate-pressure product $(p<0.01)$, and adenine nucleotide recovery (adenosine triphosphate: $19.0 \pm 1.3$ versus $4.2 \pm 0.6 ; p<0.001$; total adenine nucleotides: $37.1 \pm 2.6$ versus $12.1 \pm 2.0 ; p<0.001$ ).

Duration of protection. Hearts stored in standard University of Wisconsin solution demonstrated loss of function after 24 hour storage, whereas storage in modified University of Wisconsin solution resulted in substantially improved function which gradually decreased as storage was prolonged to 48 hours (Fig. 8). LVDP dropped to $32 \%, 32 \%, 17 \%$, and $9 \%$ of control after 24 , 30,40 , and 48 hours of storage in University of Wisconsin solution but fell to only $81 \%(p<0.001), 75 \%$ $(p<0.0001), 61 \%(p<0.001)$, and $56 \%(p<0.001)$ of control after $24,30,40$, and 48 hours of storage in modified University of Wisconsin solution, respectively. Sim.ilar differences in function were observed in LVEDV for modified University of Wisconsin solution compared with University of Wisconsin solution at 24 hours ( $94 \%$ versus $36 \%, p<0.001), 30$ hours ( $74 \%$ versus $15 \%, p<0.0001$ ), 40 hours $(51 \%$ versus $10 \%, p<0.01)$, and 48 hours of storage ( $34 \%$ versus $7 \%, p<0.01$ ). This pattern was also evident in rate-pressure product for modified University of Wisconsin solution compared with University of Wisconsin solution at 24 hours ( $100 \%$ versus $33 \%, p<0.001$ ), 30 hours ( $89 \%$ versus $27 \%, p<0.0001), 40$ hours $(65 \%$ versus $17 \%, p<0.001$ ), and 48 hours of storage ( $58 \%$ versus $7 \%, p<0.0001$ ).

Differences in other parameters, however, were not as dramatic. Heart rate after storage in modified University of Wisconsin solution was higher than that of control at all intervals of storage but was significantly higher than hearts stored in University of Wisconsin solution only at 24 and 30 hours of storage $(p<0.001)$. In addition, cor- 


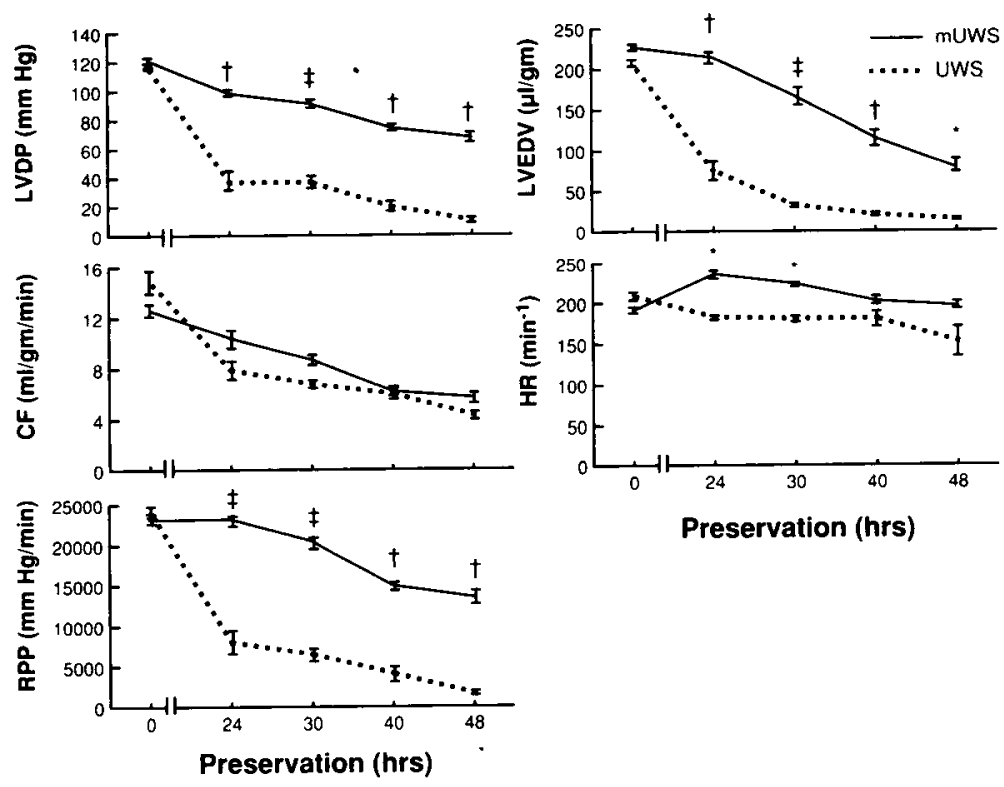

Fig. 8. Function of hearts stored for $0,24,30,40$, and 48 hours with University of Wisconsin solution with and without $\mathrm{BDM} 30 \mathrm{mmol} / \mathrm{L}$ and $\mathrm{CaCl}_{2} 1.0 \mathrm{mmol} / \mathrm{L}$. Groups were compared at each time point by Student's $t$ test; $n$ for University of Wisconsin solution $=6$ at 0 hours, 6 at 24 hours, 8 at 30 hours, 6 at 40 hours, and 6 at 48 hours; $n$ for modified University of Wisconsin solution $=7$ at 0 hours, 6 at 24 hours, 7 at 30 hours, 8 at 40 hours, and 6 at 48 hours; ${ }^{*} p<0.05, \dagger p<0.001, \ddagger p<0.0001$. See Figs. 1 and 7 for abbreviations.

onary flow decreased in both groups at nearly an equivalent rate, remaining only slightly higher in hearts stored in modified University of Wisconsin solution at 24 hours ( $83 \%$ versus $53 \%$ ) and 30 hours (65\% versus $46 \%$ ), differences which did not reach statistical significance.

\section{Discussion}

Current myocardial preservation strategies of cardioplegic arrest, hypothermic storage, and short ischemic intervals are aimed primarily at preserving levels of highenergy phosphate compounds and avoiding the devastating effects of myocardial energy depletion. The liver, kidney, and pancreas have been stored for extended periods with the University of Wisconsin solution ${ }^{1}$ without regard to energy levels. Successful preservation of the heart, however, is much more sensitive to falling levels of highenergy compounds, mainly because of the development of myocardial contracture as energy levels are depleted. ${ }^{12}$ Our approach in this study was not aimed at preserving adenosine triphosphate, but rather at preventing the deleterious myocardial events that result from energy depletion during extended storage.

BDM was selected as an adjunct to the University of Wisconsin solution because it reversibly inhibits myofilament contraction in cardiac muscle. ${ }^{13}$ BDM has also been shown to inhibit activity of the myofibrillar adenosinetriphosphatase, ${ }^{14}$ and to preserve high-energy phos- phates during myocardial ischemia. ${ }^{9}$ This probably is a result of BDM's inherent phosphatase activity, ${ }^{15}$ which appears to spare adenine nucleotides but may affect regulatory proteins which require phosphorylation to remain active in intracellular metabolism. In addition, Gwathmey, Hajjar, and Solaro ${ }^{16}$ have shown BDM to have inhibitory effects on intracellular calcium transients, and Wiggins and colleagues ${ }^{17}$ have reported that BDM inhibits sarcolemmal calcium channels. These effects might result in amelioration of the intracellular calcium overload associated with myocardial stunning and ischemic damage.

We have shown in this study that myocardial preservation is optimized when the University of Wisconsin solution is modified with BDM $30 \mathrm{mmol} / \mathrm{L}$. Without BDM in the preservative, myocardial function was depressed by approximately $50 \%$. Addition of only 15 $\mathrm{mmol} / \mathrm{L}$ produced insufficient protection, resulting in poor contractile function and severe contracture. When BDM concentration was raised to $60 \mathrm{mmol} / \mathrm{L}$, myocardial function was also diminished. Lowering the osmolarity of the $60 \mathrm{mmol} / \mathrm{L}$ group, however, resulted in markedly improved myocardial function, tending to be slightly (but not significantly) less than with $30 \mathrm{mmol} / \mathrm{L}$. Other than injury from hyperosmolarity, another possible reason for this effect is the reduction in either lactobionate or potassium concentration, which was used to decrease the 
osmolarity of the solution. It is improbable, however, that this was the cause of the improved function because the change was small $(15 \mathrm{mmol} / \mathrm{L})$, and the concentrations of these ions remained high (lactobionate at $85 \mathrm{mmol} / \mathrm{L}$, $\mathrm{K}^{+}$at $115 \mathrm{mmol} / \mathrm{L}$ ).

These data indicate that a BDM concentration of at least $30 \mathrm{mmol} / \mathrm{L}$ is necessary for extended myocardial preservation, and higher concentrations appear to be no more effective at protecting the heart from ischemic damage. The higher osmolarity resulting from addition of other compounds to the University of Wisconsin solution, however, is detrimental to the ischemic heart. The sensitivity of these hearts to changes in osmolarity is in agreement with the findings of Batty and colleagues, ${ }^{18}$ who reported that hyperosmolarity of a storage solution is detrimental to myocardial preservation. Armstrong and Ganote ${ }^{19}$ have also suggested that BDM may render the myocyte more susceptible to osmotic stress. The correct osmolarity of a solution containing BDM therefore appears to be extremely important in preservation quality. A more detailed study of the osmolarity of this modified solution may lead to further improvement in myocardial preservation.

The optimal concentration of calcium for myocardial preservation has remained controversial. Proponents of adding calcium to cardioplegic solutions have suggested that the calcium paradox may occur with storage in acalcemic solutions, and the addition of calcium results in superior postischemic myocardial function. ${ }^{20}$ More recent reports have argued that only micromolar amounts of calcium ( 50 to $100 \mu \mathrm{mol} / \mathrm{L}$ ) are necessary for prevention of this phenomenon, and higher concentrations can cause increased energy expenditure and structural myocardial contracture. ${ }^{21-24}$ In fact, improvement in 7-hour heart preservation with the University of Wisconsin solution containing calcium $0.25 \mathrm{mmol} / \mathrm{L}$ has been reported. $^{25}$ The calcium paradox, however, has not been observed as a clinically important problem in cardiac surgery, which is probably due to other factors that mitigate the absence of calcium, such as moderate hypothermia, ${ }^{26}$ trace calcium contamination of cardioplegic solutions, or noncoronary collateral blood flow, which may provide adequate calcium to the sarcolemma. Rich and Langer ${ }^{21}$ have reported, however, that as the calcium-free exposure time is prolonged, hypothermia becomes increasingly less effective at preventing the calcium paradox. With extended intervals of ischemic storage of approximately 24 to 48 hours and in an isolated environment, the calcium paradox may become more of a problem for the cardiac allograft than has been recognized in the past.

We have previously reported evidence strongly sugges- tive of a calcium paradox occurring after 24 hours of cold storage. ${ }^{9}$ Systolic dysfunction, severe myocardial contracture, and failure of diastolic relaxation were observed on reperfusion when rabbit hearts were stored in University of Wisconsin solution modified with BDM in the absence of calcium. These phenomena were completely reversed by the addition of calcium to the preservative. We also found, however, that the presence of calcium alone (without BDM) caused accelerated loss of highenergy phosphates and worsened myocardial contracture during the storage period. These sequelae were completely inhibited by the addition of BDM to the solution.

It appears, therefore, that calcium is a necessary component of a preservative for extended myocardial storage but will be effective only if inhibition of calcium-sensitive adenosine triphosphatases can be provided by a substance such as BDM. Although we did not perform an in-depth dose-response study of calcium concentrations, our data indicate that micromolar amounts of calcium are insufficient for extended myocardial preservation with this solution, which is likely due to the calcium-chelating effect of lactobionate, an integral component of the University of Wisconsin solution. Lactobionate may act as a "calcium buffer," allowing only minute amounts of free ionized calcium to bathe and diffuse through the sarcolemma. In fact, the free ionized calcium content of the University of Wisconsin solution containing $\mathrm{CaCl}_{2} 1.0$ $\mathrm{mmol} / \mathrm{L}$ has been measured in our laboratory to be approximately $0.1 \mathrm{mmol} / \mathrm{L}$ (unpublished data). Similar results of the calcium-chelating properties of the University of Wisconsin solution have been recently published. ${ }^{27}$

If modification with BDM and calcium is able to potentiate the preservation capability of the University of Wisconsin solution, then a similar effect should be apparent with other preservation solutions. We have shown, in fact, that preservation is significantly enhanced in both the St. Thomas' Hospital solution and the Stanford solution with addition of BDM and calcium. Hearts stored with the modified University of Wisconsin solution, however, exhibited significantly better preservation of function and regeneration of adenine nucleotides than did those stored in either of the other modified solutions. These findings are not surprising in light of previous reports that have shown the University of Wisconsin solution to be superior to either the Stanford solution ${ }^{28,29}$ or the St. Thomas' Hospital solution ${ }^{30,31}$ for hypothermic myocardial preservation of shorter duration. This may be due in part to the components in the University of Wisconsin solution, which protect the cell from ischemic damage, such as cellular impermeants which reduce cell swelling (lactobionate, raffinose), a vascular impermeant which protects from interstitial edema (hydroxyethyl 
starch), precursors of high-energy phosphates for improved regeneration (adenosine, phosphate), antioxidants to ameliorate reperfusion injury caused by generation of oxygen free radicals (glutathione, allopurinol), and an "intracellular" ionic composition to reduce energy expenditure and aphysiologic intracellular accumulation of ions as a consequence of diffusion. BDM has only potentiated the preservation capabilities of these components by adding its own protective effect specific for muscular tissue.

We also showed in this study that hearts stored in this modified University of Wisconsin solution were able to withstand prolonged periods of ischemic cold storage. Function was maintained at $80 \%$ to $100 \%$ of control at 24 hours, $70 \%$ to $89 \%$ at 30 hours, and $50 \%$ to $65 \%$ after 40 hours of cold storage. After 48 hours of storage, hearts stored in modified University of Wisconsin solution had function superior to hearts stored in standard University of Wisconsin solution after only 24 hours of storage. These findings do not indicate, however, that a bloodreperfused transplanted heart would function adequately after such prolonged ischemia. Further studies of an orthotopically transplanted cardiac allograft, which is able to support the recipient circulation for extended periods, will be necessary to demonstrate the importance of our findings.

Several other limitations of this study should be addressed. Although we have been able to substantially improve myocardial contractility, diastolic relaxation, and mitochondrial function, we have done little to eliminate the progressive deterioration of coronary flow observed during reperfusion. Hearts stored in either modified or standard University of Wisconsin solution demonstrated nearly identical reduction in coronary flow. Current study of endothelial and microvascular ischemic dysfunction may soon reveal methods of overcoming this problem. In addition, maintenance of postischemic heart rates above control levels is not necessarily beneficial. This finding may suggest that hearts stored in the presence of BDM may be prone to develop supraventricular tachycardia and catecholamine hypersensitivity, effects which may be attributable to alteration in membrane channels or intracellular regulatory proteins. Additional studies on these effects of BDM may be necessary before optimization of extended preservation with BDM can be attained.

In conclusion, the University of Wisconsin solution modified with BDM $30 \mathrm{mmol} / \mathrm{L}$ and $\mathrm{CaCl}_{2} 1.0 \mathrm{mmol} / \mathrm{L}$ is effective for long-term preservation of the heart in this experimental model. Preservation might be further improved by optimization of the solution osmolarity. Further study of these and other solution characteristics is warranted to tailor the preservative specifically to the needs of the ischemic heart. With modifications such as these, truly successful long-term myocardial preservation may eventually become a reality.

\section{REFER E N CES}

1. D'Alessandro AM, Kalayoglu M, Sollinger HW, et al. Current status of organ preservation with University of Wisconsin solution. Arch Pathol Lab Med 1991;115:30610.

2. Jeevanandam V, Barr MC, Auteri JS, et al. University of Wisconsin solution versus crystalloid cardioplegia for human donor heart preservation: a randomized blinded prospective trial. J THORAC CARDIOvasC SURG 1992;103: 194-9.

3. Ko W, Zelano JA, Lazzaro R, et al. Superiority of the University of Wisconsin solution over simple crystalloid for extended heart preservation: a study of left ventricular pressure-volume relationship. J THORAC CARDiovasC SURG 1992;103:980-92.

4. Jeevanandam V, Auteri JS, Sanchez JA, et al. Cardiac transplantation after prolonged graft preservation with the University of Wisconsin solution. J THORAC CARDIOVASC SURG 1992;104:224-8.

5. Ploeg RJ, Goossens D, McAnulty JF, et al. Successful 72-hour cold-storage of dog kidneys with UW solution. Transplantation 1988;46:191-6.

6. Jamieson NV, Sundberg R, Lindell S, et al. Preservation of the canine liver for 24-48 hours using simple cold storage with UW solution. Transplantation 1988;46:517-22.

7. Wahlberg JA, Love R, Landegaard L, et al. 72-hour preservation of the canine pancreas. Transplantation 1987;43: 5-8.

8. Stringham JC, Southard JH, Hegge J, Triemstra L, Fields BL, Belzer FO. Limitations of heart preservation by cold storage. Transplantation 1992;53:287-94.

9. Stringham JC, Paulsen KL, Southard JH, Fields BL, Belzer FO. Improved myocardial ischemic tolerance by contractile inhibition with 2,3-butanedione monoxime. Ann Thorac Surg 1992;54:852-60.

10. Billingham ME, Baumgartner WA, Watson DC, et al. Distant heart procurement for human transplantation. Circulation 1980;62(Suppl):I1 1-9.

11. Takahashi A, Braimbridge MV, Hearse DJ, Chambers DJ. Long-term preservation of the mammalian myocardium: effect of storage medium and temperature on the vulnerability to tissue injury. J ThORAC CARDIOvaSC SURG 1991; 102:235-45.

12. Nichols CG, Lederer WJ. The role of ATP in energy-deprivation contractures in unloaded rat ventricular myocytes. Can J Physiol Pharmacol 1990;68:183-94.

13. Perreault CL, Muleri LA, Alpert NR, Ransil BJ, Allen PD, Morgan JP. Cellular basis of negative inotropic effect of 2,3-butanedione monoxime in human myocardium. Am J Physiol 1992;263:H503-10. 
14. Higuchi $\mathrm{H}$, Takemori S. Butanedione monoxime suppresses contraction and ATPase activity of rabbit skeletal muscle. J Biochem 1989;105:638-43.

15. Ellin RI, Wills JH. Oximes antagonistic to inhibitors of cholinesterase. J Pharm Sci 1964;53:995-1007.

16. Gwathmey JK, Hajjar RJ, Solaro RJ. Contractile deactivation and uncoupling of crossbridges: effects of 2,3butanedione monoxime on mammalian myocardium. Circ Res 1991;69:1280-92.

17. Wiggins JR, Reiser J, Fitzpatrick DF, Bergey JL. Inotropic actions of diacetyl monoxime in cat ventricular muscle. J Pharmacol Exp Ther 1980;212:217-24.

18. Batty PR, Hicks GL, DeWeese JA, Wang T. Optimal osmolarity for cold storage of the cardiac explant. J Surg Res 1990;48:601-5.

19. Armstrong SC, Ganote CE. Effects of 2,3-butanedione monoxime (BDM) on contracture and injury of isolated rat myocytes following metabolic inhibition and ischemia. $J$ Mol Cell Cardiol 1991;23:1001-14.

20. Yamamoto F, Braimbridge MV, Hearse DJ. Calcium and cardioplegia: the optimal calcium content for the St. Thomas' Hospital cardioplegic solution. J THORAC CARDIOvASC SURG 1984;87:908-12.

21. Rich TL, Langer GA. Calcium depletion in rabbit myocardium: calcium paradox protection by hypothermia and cation substitution. Circ Res 1982;51:131-41.

22. Robinson LA, Harwood DC. Lowering the calcium concentration in St. Thomas' Hospital cardioplegic solution improves protection during hypothermic ischemia. J THORaC Cardiovasc Surg 1991;101:314-25.

23. Kinoshita K, Oe M, Tokunaga K. Superior protective effect of low-calcium, magnesium-free potassium cardioplegic solution on ischemic myocardium: clinical study in comparison with St. Thomas' Hospital solution. J THORAC CARdIOVASC SURG 1991;101:695-702.

24. Torchiana DF, Love TR, Hendren WG, et al. Calcium-induced ventricular contraction during cardioplegic arrest. J ThORAC Cardiovasc Surg 1987;94:606-13.

25. Batty PR, Hicks GL, DeWeese JA, Wang T. The calcium requirement for hypothermic storage of the cardiac explant. Curr Surg 1989;46:313-16.

26. Baker JE, Bullock GR, Hearse DJ. The temperature dependence of the calcium paradox: enzymatic, functional and morphological correlates of cellular injury. J Mol Cell Cardiol 1983;15:393-411.

27. Burgmann H, Rechendorfer H, Sperlich M, Doleschel W, Spieckermann PG. The calcium chelating capacity of different protecting solutions. Transplantation 1992;54: 1106-8.

28. Swanson DK, Pasaoglu I, Berkoff HA, Southard JA, Hegge JO. Improved heart preservation with UW preservation solution. J Heart Transplant 1988;7:456-67.

29. Stein DG, Drinkwater DC, Laks H, et al. Cardiac preservation in patients undergoing transplantation: a clinical trial comparing University of Wisconsin solution and Stanford solution. J THORAC CARDIOVASC SURG 1991;102:65765.

30. Yeh T, Hanan SA, Johnson DE, et al. Superior myocardial preservation with modified UW solution after prolonged ischemia in the rat heart. Ann Thorac Surg 1990;49:932-9.

31. Mankad PS, Severs NJ, Lachno DR, Rothery S, Yacoub MH. Superior qualities of University of Wisconsin solution for ex vivo preservation of the pig heart. J THORAC Cardiovasc Surg 1992;104:229-40. 